\title{
ДОСЛІДЖЕННЯ РАНОЗАГОЮВАЛЬНОї ДІЇ МАЗІ 3 ЕКСТРАКТОМ СОСНИ ЗВИЧАЙНОї
}

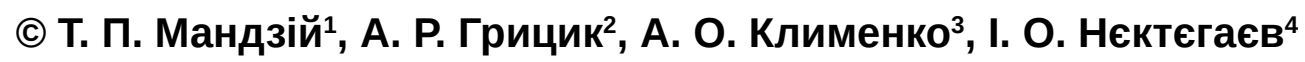 \\ 1,2,3ДВНЗ «Івано-Франківський національний медичний університет» \\ ${ }^{4}$ ДВНЗ «Львівський національний медичний університет імені Данила Галицького»
}

\begin{abstract}
Резюме: у статті представлено результати дослідження ранозагоювальної дії мазі з екстрактом сосни звичайної, яка показала перевагу в ранозагоювальній активності над препаратом порівняння - «Альгофрін - форте» та відсутністю побічних впливів на внутрішні органи тварин.
\end{abstract}

Ключові слова: фрармакологічне вивчення, мазь з екстрактом сосни звичайної, рановий процес.

Вступ. Арсенал лікарських препаратів, призначених для місцевого консервативного лікування ран, неухильно зростає.

На даний час ще не існує універсального препарату, придатного для використання в усіх фразах ранового процесу: гнійно-некротичній, регенерації (утворення грануляційної тканини) і рубцювання, оскільки лікування на кожній фразі потребує диференційованого підбору препаратів із різним механізмом дії [1 - 3].

Незамінною лікарською фрормою в лікуванні ранових пошкоджень залишаються мазі, інтерес до яких в останні роки зріс. Вони виявляють м'яку дію і малу токсичність на фроні високої ефективності, а комплекс біологічно активних речовин має різнонаправлений вплив. Це дає можливість їх використовувати 3 мінімальною кількістю побічних ефектів.

Опрацьовані літературні джерела показали перспективність розробки лікарської фрорми з ефрірною олією сосни звичайної, до складу якої входять пінен, карен, терпінеол, лімонен та інші терпеноїди [4 - 5].

Мета роботи - вивчення ранозагоювальної активності мазі з екстрактом сосни звичайної, яка має здатність впливати на загоєння ранових процесів.

Mетоди дослідження. Ранозагоювальну активність вивчали в експериментах in vivo на 32 білих безпородних щурах відповідно до «Загальноетичних принципів експериментів на тваринах» (Україна, 2001), узгодженими 3 «Європейською конвенцією про захист тварин, які використовуються для експериментальних і інших наукових цілях».

Експеримент проводили на тваринах масою 170 192 г, які знаходились на загальному раціоні харчування і утримувались в однакових умовах.

Усіх тварин було поділено на 4 групи по 8 щурів у кожній: 1 група - контрольна; 2 група - отримувала лікування маззю з екстрактом сосни звичайної; 3 група - наносили основу, 4 група - отримувала лікування препаратом порівняння «Альгофрін - фрорте».
Для відтворення моделі лінійної рани щурам під барбаміловим наркозом (0,8 мл 1 \% водного розчину барбамілу на 100 мг маси тіла) в асептичних умовах (операційну ділянку обробляли 5 \% спиртовим розчином йоду), попередньо позбавивши шерсті, висікали шматок шкіри розміром $1 \times 1 \mathrm{~cm}$.

Препарат наносили в лікувальному режимі 2 рази на добу впродовж 14 діб з моменту моделювання патології. Визначивши площу рани в експериментальних тварин у кожній серії, вираховували середню площу (M $\pm m)$, відсоток зменшення площі рани від початкового розміру [6 - 8].

Як один з фракторів, які визначають швидкість репаративних процесів, є вміст білка, тому в сироватці крові визначали вміст загального білка і молекул середньої маси.

Результати й обговорення. Результати дослідження репаративної активності мазі 3 екстрактом сосни звичайної представлено в таблиці 1.

Результати, наведені в таблиці 1, свідчать, що прискорення загоєння ранового процессу спостерігається при застосуванні мазі з екстрактом сосни звичайної (зменшення площі рани до $(50,10 \pm 3,34)$ і $(2,13 \pm$

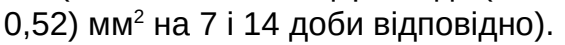

Таким чином, мазь з екстрактом сосни звичайної як засіб для лікування ран в експерименті переважає порівняно 3 референт - препаратом (4 група) і забезпечує загоєння ранового дефекту в більш короткі терміни.

При візуальному спостереженні у групі № 2 спостерігається зміна площ рани на 7 і 14 добу, які становлять 50,10 та 2,13 мм² відповідно.

Розвиток ранового процесу супроводжувався зміною білкового обміну та рівнем молекул середньої маси (загальний білок у тварин контрольної групи і групи № 2 становить $(45,6 \pm 1,17)$ г/л і $(57,4 \pm 2,9)$ г/л, відповідно, вміст молекул середньої маси - $(0,29 \pm$ 0,02) у. о. і $(0,22 \pm 0,01)$ у. о. відповідно) [9].

ISSN 2312-0967. Pharmaceutical review. 2015. № 4 
Фармакологічні дослідження біологічно активних речовин Pharmacological researches of biologically active substances

Таблиця 1. Репаративна активність мазі з екстрактом сосни звичайної на моделі лінійної різаної рани у щурів

\begin{tabular}{|l|c|c|c|c|}
\hline \multirow{2}{*}{ Групи тварин } & \multicolumn{2}{|c|}{ Площа рани, мм² } & Загальний білок, г/л, & Молекули середньої \\
\cline { 2 - 3 } & 7 доба & 14 доба & $\bar{x} \pm \Delta \bar{x}$ & маси, у.о., $\bar{x} \pm \Delta \bar{x}$ \\
\hline Група № 1, контроль & $75,20 \pm 2,27$ & $21,70 \pm 2,26$ & $45,6 \pm 1,17$ & $0,29 \pm 0,02$ \\
\hline $\begin{array}{l}\text { Група № 2, мазь 3екстрактом } \\
\text { сосни 3вичайної }\end{array}$ & $50,10 \pm 3,34$ & $2,13 \pm 0,52$ & $57,4 \pm 2,9$ & $0,22 \pm 0,03$ \\
\hline Група № 3, основа & $69,00 \pm 1,71$ & $9,60 \pm 2,73$ & $46,2 \pm 1,29$ & $0,27 \pm 0,01$ \\
\hline $\begin{array}{l}\text { Група № 4, «Альгофрін - } \\
\text { фрорте» }\end{array}$ & $62,30 \pm 2,06$ & $7,80 \pm 2,24$ & $53,7 \pm 2,9$ & $0,22 \pm 0,04$ \\
\hline
\end{tabular}

Висновки. 1. Результати проведених досліджень свідчать, що застосування мазі з екстрактом сосни звичайної при лікуванні ранового процесу забезпечує загоєння рани в більш короткі терміни.
За репаративною активністю мазь 3 екстрактом сосни звичайної при нанесенні на ранову поверхню проявляє більш виражену активність порівняно 3 ресрерент-препаратом.

\section{Список літератури}

1. Шалимов О. О. Сучасне медикаментозне лікування ран / О. О. Шалимов, В. Ф. Саєнко, Б. М. Даценко // Відомча інструкція.- К., 2002.- 37 с.

2. Martin P. Inflammatory cells during wound repair: the good, the bad and the ugly / P. Martin, S. J. Leibovich // Trends Cell Biol.- 2005.- V. 15, № 4.- P. 599-607.

3. Velnar T. The wound healing process: an overview of the cellular and molecular mechanisms / T. Velnar, T. Bailey, V. Smrkolj // J. Int. Med. Res.-2009.- V. 37, № 5.- P. 15281542.

4. Застсоування рослин класу хвойні у медицині. Родина Соснові (огляд літератури) / Т. М. Козименко, Л. Г. Дудченко, Т. Ю. Грабова [та інші] // Фітотерапія. Часопис. - № 2. - К. : 2014. - С. $34-39$

5. Ранозаживляющая активность мази, содержащей эсрирное масло травы тысячелистника пойменного
/ С. Д. Тржецинский, В. И. Мозуль, Г. А. Жернов [и др.] // Актуальні питання фрармацевтичної і медичної науки та практики. - № 2 (15). - 2014. С. $50-53$.

6. Доклінічні дослідження лікарських засобів: Методичні рекомендації / за ред. чл.-кор. АМН України О. В. Стефранова. - К. : Авіцена, 2001. - 528 с.

7. Теория и практика местного лечения гнойных ран (проблемы лекарственной терапии) / под ред. Б. М. Даценко. - К. : Здоров'я, 1995. - 383 с.

8. Раны и раневая инсрекция: Руководство для врачей / под ред. М. И. Кузина, Б. М. Костючонок. - 2-е изд. - М. : Медицина, 1990. - 592 с.

9. Камышников В. С. Справочник по клинико биохимической лабораторной диагностике: в 2 т. - Мн. : Беларусь, 2000. - Т. 1. - 495 с.

\section{ИССЛЕДОВАНИЕ РАНОЗАЖИВЛЯЮЩЕГО ДЕЙСТВИЯ МАЗИ С ЭКСТРАКТОМ СОСНЫ ОБЫКНОВЕННОЙ}

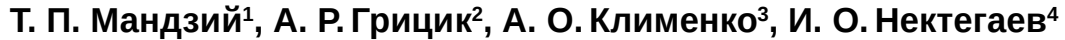 \\ 1,2,3ДВНЗ «Ивано-Франковский национальный медицинский университет» \\ ${ }^{4}$ ДВНЗ «Львовский национальный медицинский университет имени Данила Галицкого»}

Резюме: изучено ранозаживляющее действие новой мази с экстрактом сосны обыкновенной по сравнению с препаратом "Альгосин - форте". Анализ полученных результатов свидетельствует о целесообразности использования мази с экстрактом сосны обыкновенной при резаных ранах.

Ключевые слова: фрармакологическое изучение, мазь с экстрактом сосны обыкновенной, раневой процесс.

ISSN 2312-0967. Фармацевтичний часопис. 2015. № 4 
Фармакологічні дослідження біологічно активних речовин

Pharmacological researches of biologically active substances

\section{STUDY OF WOUND HEALING OINTMENT WITH PINE EXTRACTS}

\section{T. P. Mandzii' ${ }^{1}$, A. R. Hrytsyk², A. O. Klymenko ${ }^{3}$, I. O. Nyektyehayev ${ }^{4}$}

1,2,3 SHEI «Ivano-Frankivsk National Medical University»

${ }^{4}$ SHEI «Lviv National Medical University by Danylo Halytskyi»

Summary: there was studied the effect of a new wound healing ointments with extract of pine compared with the drug «Alhofin - forte». Analysis of the results shows the feasibility of using an ointment with extract of pine with cut wounds.

Key words: pharmacological study, ointmet with extract of pine, wound process. 